\title{
Protest Consciousness of the Russian Youth (on the Example of the Russian Far East)
}

\section{Protesta la conciencia de la juventud rusa (en el ejemplo del Lejano Oriente ruso)}

\author{
Egor Borisovich Marin \\ Maritime State University named after Admiral G.I. Nevelskoy, Russia \\ Far Eastern Federal University, Russia \\ https://orcid.org/0000-0002-0409-5065
}

Received 09-08-20 Revised 10-10-20

Accepted 20-12-21 On line 03-17-21

*Correspondencia

Email: egor-marin@yandex.ru

(C) Universidad San Ignacio de Loyola, Vicerrectorado de Investigación, 2021.

Este artículo se distribuye bajo licencia CCBY-NC-ND 4.0 Internacional (http://creativecommons.org/licenses/by-nc-nd/4.0/). 


\section{Summary}

In Russian history and culture, various kinds of protests and uprisings have always played an important role. One can recall periodical civilian riots and uprisings in the Russian Empire; the revolution of 1917 that changed the world history. Political processes in a country have often been a pendulum swinging between extremes such as passive loyalty and riot. In recent years, a relative stability of society and power has been achieved, the foundations of which are sometimes referred to as a social contract. However, the beginning of protest in Russian society is increasingly shows itself. The publication presents materials of semantic reconstruction of ideas about various forms of social protest among Russian youth. The study made it possible to reconstruct structural and informatory characteristics of young people's ideas about five significant forms of collective protest: petition, rally, strike, riot and uprising. Comparative analysis shows that the closest form of protest to young people is such a form of protest as a rally, such a form as a petition is also positively assessed. Young people don't associate radical forms of protest, such as riot and uprising, with values and goals that are meaningful to them.

Keywords: Representation, Protest, Psychosemantics, Russia, Youth.

\section{Resumen}

En la historia y la cultura rusas, varios tipos de protestas y levantamientos siempre han jugado un papel importante. Uno puede recordar los disturbios y levantamientos civiles periódicos en el Imperio Ruso; la revolución de 1917 que cambió la historia mundial. Los procesos políticos en un país a menudo han sido un péndulo que oscila entre extremos como la lealtad pasiva y los disturbios. En los últimos años se ha logrado una relativa estabilidad de la sociedad y del poder, cuyos fundamentos a veces se denominan contrato social. Sin embargo, el comienzo de la protesta en la sociedad rusa se muestra cada vez más. La publicación presenta materiales de reconstrucción semántica de ideas sobre diversas formas de protesta social entre la juventud rusa. El estudio permitió reconstruir las características estructurales e informativas de las ideas de los jóvenes sobre cinco formas significativas de protesta colectiva: petición, concentración, huelga, motín y sublevación. El análisis comparativo muestra que la forma de protesta más cercana a los jóvenes es una forma de protesta como una manifestación, una forma como una petición también se evalúa positivamente. Los jóvenes no asocian formas radicales de protesta, como disturbios y levantamientos, con valores y objetivos que les sean significativos.

Palabras clave: Representación, Protesta, Psicosemántica, Rusia, Juventud.

\section{Relevance}

The Russian Far East is quite an interesting region in terms of protest activity. Over the past two or three years, there have been noticeable political protests. One can recall the wave of spontaneous protests during the elections of the governor in Vladivostok in 2018. Recently, Khabarovsk attracted attention with its not incurious events in the summer of 2020. Rallies of solidarity with Khabarovsk are held in many other cities of the region.

Is the most recent surge of protests in the region an accidental phenomenon, or the protest potential, especially among young people, is growing faster than it was expected? This question is still awaiting to be studied.

In most of the social and political protests in recent years, young people have been playing an important role. By virtue of its social and psychological characteristics, it is always a boundary and most active social stratum. And today new generations are actively entering the 
political arena in our country. Younger and younger participants are noticeable in street protests. Does this mean that new generations of Russians are more inclined to protest and have a more positive attitude towards it?

Based on this, it seems useful to turn to the analysis of a protest consciousness of the Russian youth. We will do this using the example of the Far Eastern youth. In the course of this research, we undertook a study of structural and informatory characteristics of the protest consciousness of young people, as well as a comparison of ideas about protest in two age groups: student youth aged 18-24 and young adults aged 25-30.

\section{Previous Study of The Topic}

Studies of ideas about political phenomena, as well as psychological mechanisms of political phenomena are carried out in several directions.

Russian political psychology is one of the most significant areas. A number of valuable studies were carried out at the department of sociology and psychology of politics, Faculty of Political Science, Moscow State University named after Lomonosov. Researchers such as E.B. Shestopal, A.L. Zverev, S.V. Nesterova, I.S. Palitai have developed their own methodology for studying images of political phenomena, including images of politicians and parties (Shestopal, Novikova-Grund, 1996; Shestopal et al., 2012a, 2012b; Zverev et al., 2016).

When developing their approach, they relied upon the idea that the image of political objects contains both a rational component and an unconscious one. Therefore, a full analysis of these phenomena requires a combination of sociological and psychological methods. The rational level was studied by the focused interview method, and the unconscious level was studied by the associative experiment and projective methods.

In the course of one of the most significant and large-scale studies of the mass political consciousness of Russians in 2016, the authors analyzed both rational and unconscious (using projective methods, associations and the method of unfinished sentences) aspects of the images of politicians and power in Russia. Summarizing the research results, the authors came to the conclusion that the images of the current government are viewed by the population from the point of view of their moral and ethical attractiveness. This approach seems to be effective and based on a serious methodology. However, it has not yet studied in detail the topic of perception of protest.

The structure of mechanisms of collective protest behavior was considered within the framework of various socio-psychological trends. One of the first attempts to explain participation in protests was made within the framework of the theory of relative deprivation by J. Davis and S. Stauffer (1959). Experiencing the group deprivation, group members try to either, motivated by anger, change their position - which directly stimulates social protest - or, experiencing depression, give up fight.

At the moment, there are several socio-psychological models of collective protest activity. Thus, the model of collective activity based on social identity was developed by Martin van Zomeren et al. (2008). Zomeren concluded that collective activity is generated by a combination of three factors: identity with a group in an unfair position, group anger (emotions), and collective effectiveness (perception of the group's ability to cope with problems). Moreover, it is identity that actualizes other factors.

In some works, two emotional paths of protest have been identified: the path of anger, based on efficiency, leading to normative action, and the path of contempt, leading to abnormal behavior when legal channels are closed (Wright et al., 1990; Kamans et al., 2011). 
In his model, Van Stekelenburg has combined resentments, efficiency, personality and emotions. The model assigns a central, integrating role to identification processes.

The influence of interaction in social media on the propensity to participate in politics has also been studied (McClurg: 2003; Klandermans et al.: 2008). Social media provides resources and networking opportunities for disaffected people.

Thus, in socio-psychological models of protest behavior, it is viewed as the result of several main factors: social identity, group emotions, collective effectiveness. Under the pressure of problems and experiencing group deprivation, a group is looking for a way out. The choice of one or another way of implementing a protest depends on the specific configuration of these factors.

Russian sociology has also made a great contribution to the study of protest.

In our country, such authors as R.Kh. Salakhutdinova, O.I. Gaba (2015), A.V. Petrushina (2011), Yu. A. Akunina (2011) made a great contribution to the study of the problem of social protest. Various aspects of protest moods and youth behavior are productively studied by such authors as G.V. Baranova (2012), Yu.A. Krasin (2012), D.Volkov (2012), M.M. Nazarov (1995), E.N. Solomatina (2014).

According to G.V. Baranova (2012, p. 143), social activity has various forms, both constructive and more contradictory, up to destructive forms of protest activity. D.V. Bushuev (2012, p. 15) comprehends protest behavior as a type of political participation, which is characterized by public expression by an individual or a social group of dissatisfaction with the socio-political system through protest actions. O.I. Gaba (2015, p. 148), analyzing the reasons for protest activity of young people, writes about inflated claims of young people to themselves and others, realization of impossibility of self-actualization in full (subjective factor), catalyzed by external social and political conditions (objective factor).

Thus, within the framework of sociological analysis, many social reasons for youth protest were revealed.

A relatively new approach to the study of psychological aspects of political phenomena is the psychosemantic approach. In the 1990s, the methods of psychosemantics began to be used to study political mentality in our country. Thus, V.F. Petrenko and O.V. Mitina $(1997 ; 2017)$ developed their own approach to the study of a political mentality using psychosemantic methods; they reconstructed a semantic space of political parties, as well as the image of the state.

Despite the considerable achievements of this approach in the study of political mentality, it has not yet been applied to the analysis of protest consciousness. At the same time, this approach has undoubted opportunities for in-depth analysis of beliefs about politics, structures of political thinking and affective components of political consciousness. Therefore, we made an attempt to apply psychosemantic methods to study the concept of protest.

\section{Methods}

This article describes reconstruction of the ideas of different groups of young people about the forms of social and political protest, carried out using a psychosemantic approach.

Psychosemantic methods include such methods of studying mental phenomena that make it possible to identify individual and group systems of senses and meanings and to establish connections between them. Moreover, the sense is broader than the meaning. The meaning is only an object itself, and the sense or senses surpass it. Sense is the intended purpose 
of an object, the benefit from it (therefore, devoid of sense means senseless). In addition, the sense of a phenomenon for different people may be different (personal sense). Senses can be based on context, past experience and understanding of a phenomenon.

To conduct our research, we have chosen such a flexible and reliable method as an associative experiment, as well as the method of semantic differential (SD).

The association method belongs to one of the first projective methods and the most developed technique of semantic analysis.

An associative experiment allows you to study the perceptions of a group of people about the object under study, study the lexicon and lexical connections, search for key incentives and rating scales when creating semantic tools, etc.

Use of the method of free verbal associations makes it possible to identify the system of respondents' perceptions, being a tool with a large number of degrees of freedom (Serkin: 2008). Use of this method allows us to identify the emotional aspects of perceptions about protest.

Characteristics of content and methods of application of psychosemantics methods are presented in the works of V.F. Petrenko (2005; 2016), V.P. Serkin (2008) and A.G. Shmelev (1988).

During the associative experiment, the respondents were asked to give several associations for each stimulus. The following forms of collective social protest were proposed as incentives: petition, rally, strike, riot, uprising.

The primary list of forms of collective protest was compiled based on the analysis of scientific literature. The media content on social and political protest was also taken into account. In the event that there are two forms of protest that are very close in meaning (for example, riot and rebellion), we left one of them in the final list of incentives. An expert assessment of these forms was carried out by representatives of the two studied age groups of young people, which have assessed popularity and comprehensibility of each of the presented forms. The list included forms of collective protest that are relevant and familiar to young people. The forms presented in this list are arranged in order of increasing activity and severity of the protest. The list includes both conventional and non-conventional forms of protest political participation.

In the course of the study, the respondents' perceptions about five forms of collective protest behavior: petition, rally, strike, riot and uprising was reconstructed using the associative method.

To analyze the data obtained, a personal classification of associative material was compiled. When compiling the classification, the structural-functional approach played a leading role. The resulting classification, on the one hand, reflects the internal structure of the resulting set of associations. We lined up the categories "following" the obtained material. In addition, the classification was built taking into account the research objectives.

The primary list of associations we obtained from the respondents for each stimulus was classified according to the indicated method and reduced. Identical associations have been merged. For the analysis, we used non-random, repeated reactions in the group (group associative universals). With a group size of 5 to 99 persons, associations with a frequency of $\mathrm{v}=4$ (significance level of the selected descriptions $\mathrm{p}=0.01$ ) should be considered non-random (significant) (Serkin, 2009, p. 24). We also included associations with a frequency of $v=3$ to the significant associations. 
In addition to the associative experiment, the method of semantic differential (SD) was used. SD is a set of scales used to identify subjective perceptions of tested subjects.

We have compiled a pilot version of the SD for assessing the protest, including 17 scales. The scales of well-known SD were taken as a basis. Some of the scales describing "strength", "activity" and "assessment" of a phenomenon were borrowed from the classic SD by Charles Osgood. The second group of scales of a personalized nature was taken from the personalized SD of A.G. Shmelev (1988). As a result, a compact method was drawn up for assessing the forms of protest. Sofia Varlamova, a student of the specialty "psychology" of FEFU, took part in preparation of the methodology.

\section{Sample}

The poll was conducted in April - May 2020 in Vladivostok. A total of 130 people took part in the study.

The study involved two age groups:

1. Student youth aged 18 to 24 (in the amount of 70 people). This group consisted of students of higher educational institutions of the city in different areas of studying.

2. Youth aged 25-30, or young adults (60 people). This group included young people of various professions, with different levels of education.

10 people of each age were interviewed (10 people aged 18, 10 people aged 19, and so on). The ratio of women and men in the sample was equal.

These two groups were selected for the survey due to the fact that among the categories of young people it is they who play the most active role in the life of the region.

The hypothesis of the research was an assumption that the ideas about protest among young people of different ages will have specific features.

\section{Discussion}

Youth perception of a petition. In the course of an associative experiment, 269 associations for the stimulus "petition" were obtained from the age group 18-24 years old, and 266 associations from the age group 25-30 years old. Associative universals with a frequency $\mathrm{v}=3$ were highlighted from the material obtained. In the category of "values and goals" there are prominent associations with change, rights, attracting attention. Moreover, young adults have more such associations. This means that perception of this form of protest and expression of opinion is associated with a number of important meanings for both groups of young people. The petition in the minds of the respondents is associated with a hope for change, with protection of rights, an ability to draw attention to certain problems.

In the category "characteristics of the phenomenon", characteristics that reflect the purpose of a petition and synonymous concepts prevail: this is an application, a contract, a demand, a request, an appeal. The abundance of associations in this category shows that this form of political participation by young people from both groups is very well known and understood.

A number of associations link petitions to IT technologies such as the Internet and the Change.org online petition service. It can be assumed that the format of petition is fully inscribed in the modern environment and is understandable to young people. 
This form of protest in the minds of respondents is not connected with the past, with the legacy of past eras. It is perceived as quite modern phenomenon.

Despite the fact that this form of protest is well understood by young people, in the minds of both groups there are such associations as "useless", "ineffective". Moreover, in the minds of young adults, these associations are more pronounced, there are such group associations as "ineffective" (10), "useless" (9), "no result" (4), "disappointment" (3).

The respondents aged 25-30 are disappointed with the ineffectiveness of this form of expressing their opinion. We believe this is an important fact, indicating that this important channel for expressing the opinion of the masses and peaceful protest is not fully working, some of the respondents are disappointed in it.

It is noteworthy that petition is associated with peaceful expression of will of young people. In the category of "protest" (as opposed to other forms of protest), there are almost no associations with forceful pressure on the authorities, violence and revolution. We can say that in the protest consciousness of young people, the petition stands somewhat apart, having little association with more active and harsher forms of protest activity.

Thus, young people have a good understanding of this form of protest and understand its significance. Collectively, signing petitions has important senses.

A petition is associated in the minds of the respondents with the hope for change, with protection of rights, an ability to draw attention to certain problems. At the same time, there is doubt and distrust in effectiveness of this method of defending one's rights.

As we believe, the potential of this form of expression of public opinion and protest for one reason or another is not fully revealed. The state leadership should pay attention to its capabilities.

Youth perception of a rally. When conducting a survey, 325 associations were received from a group of 18-24 years for the stimulus "rally". The 25-30 age group provided 292 associations. In the category "values and goals" there are strong associations with key political and existential values. Both groups associate rallies with such concepts as freedom, rights, justice, democracy. Moreover, in the youth group, associations with freedom (10), will (3), and rights (7) are more pronounced. We believe that such a form of public activity as a rally is consonant with the heightened desire of this generation for freedom.

As for young adults, there are such additional associations as "self-expression" and "opinion". For this age group, participation in rallies feels like self-realization, an opportunity to be heard.

Associations with the concept of justice indicate a certain desire to fight for justice through these mass actions. That is, rallies (probably, as well as related demonstrations) are viewed as an instrument of struggle for justice, protection of their rights. Both groups associate rallies with the desire for change, the hope for change. In addition, this form of activity is seen as an attribute of democracy.

In the category of "negative symbolism", both age groups associate rallies with discontent, which is logical. In addition, there is an association with corruption and injustice, which most likely relate to the reasons for rallies. 
In the semantic field of the "rally" stimulus, there is also a group of associations with repressive measures: suppression, arrests in the youth group. The group aged 18-24 has the association "meaningless", which may mean doubts about usefulness of this form.

In the category of "protest" we see that in both groups rallies are associated with protest, while in the youth group they are at an unconscious level associated with struggle, rebellion. For older youth, rallies are perceived as more peaceful, associated with a march or a demonstration.

Both groups tend to associate participants in rallies more often with the reference to "the public" and "people" than with the crowd. For both groups, the subjects of protest rallies are, on the one hand, the public, people, on the other hand, the authorities and the police. There is also an association "opposition", referring to the role of opposition forces in organizing rallies. It seems important that the participants in rallies are "the public", "people" for the youth. It can be assumed that rallies are seen as an expression of public opinion, a kind of form of direct democracy. The association "power" can mean both the side opposing the protesters, and the power itself as the power in the country. In this case, a rally is perceived as a form of a race for power.

In the category "leaders" were the figures of the President V. Putin and the oppositional organizer of rallies A. Navalny. These figures are in opposition to each other. The power in the public mind is present as the second side of protest events. One pole of the protests is "the public" and "people" (which sometimes is also a "crowd"), the other side is the power.

In the category "characteristics of the phenomenon" there are attributes of rallies, such as posters, slogans, demands, street, square. Attributes and conditions are appropriate for the urban environment. At the same time, a group of 25-30 years old distinguishes between the concepts of sanctioned and spontaneous rallies, is more literate in political and legal terms.

In the collective memory of the 25-30 years old group, there are images of protests in the Bolotnaya Square, the Maidan and protests against retirement age increase.

As this analysis has shown, for both groups of young people, protest rallies are an expression of an existential need for freedom.

Such a form of political participation as rallies is consonant with the young people's psychology both at the unconscious and at the conscious levels. The rallies are perceived mostly positively, associated with key political and existential values. Both groups associate rallies with such concepts as freedom, rights, justice, democracy. This form of protest is perceived by young people as a manifestation of direct democracy, active defense of rights and justice in the urban environment.

Perceptions of a strike. In the course of the survey, 284 associations for the stimulus "strike" were received from the age group 18-24 years old, and 285 associations from the age group 25-30 years old. In the category "values and goals" there are associations with rights and economic values ("wages"). The category of "values and goals" in reconstruction of perceptions of a strike is less saturated than in reconstruction of perceptions of a rally and a petition. It is almost not associated with political and existential values, and is mainly perceived as a means of struggle for economic rights.

In both groups, the subjects of the strike are, on the one hand, workers and the trade union, on the other hand, representatives of an enterprise administration and the authorities. Most often, the participants in the strike are referred to as "workers" in the materials of associations. It means that this form of protest is mainly associated in the minds of young people with industry. This is confirmed by such associations as "plant", "enterprise". 
The strike for both groups of young people is linked with demands, a plant, refusal to work. The reason for it is dissatisfaction, for the group of 18-24 years - also deception. A pronounced association in both groups is also "hunger", most likely, this means a connection with such a form of protest as a hunger strike. In both groups, a strike is associated with fatigue, and for young adults it is also associated with the concept of "unsuccessful".

In the category of "protest" there are associations with riot and struggle. This form is seen as an active and rather harsh form of protest.

In the category "historical and cultural connotations" there are associations with Europe. This form of protest is indeed historically associated with Europe, perhaps a strike is perceived as a "Western" form of protest. The concept of "general strike" is most likely associated with a historical memory of the mass protest in the Russian Empire. In a group of 25-30 years old, strikes are associated with miners, which may be a memory of the protests of the 1990s.

This form of protest is perceived by young people as an active struggle for their rights. At the same time, it is associated more with workers, the conditions of an industrial enterprise. Such a form of protest as a strike is almost not associated with political and existential values; it is mainly perceived as a means of fighting for economic rights. At the same time, it is well known to the youth of both groups, has connections with historical memory.

Perception of a riot. In the course of the associative experiment, 270 associations for the stimulus "riot" were obtained from the 18-24 years old age group, and 267 associations from the 25-30 years age group. Young people in both groups are approximately equally familiar with this phenomenon. When analyzing associations to the stimulus "riot", it is noteworthy that the category of "values and goals" is almost unfilled. It cannot be ruled out, of course, that for some of the respondents, the goal is the struggle itself. But if you analyze the associative field from the point of view of political, social or existential values and goals of the struggle, then there are very few of them. The youth group has only such an association as "change of power".

On the contrary, the category "negative symbolism" is filled with rich content. Both groups have such group associations as "bloody", "crime", "death", "chaos". At the same time, the group aged 18-24 has more such associations. A riot in this group is associated with destruction, anarchy, fear. Semantic analysis reveals an abundance of negative associations that link a riot with blood and destruction. On the contrary, there is almost no connection with creation.

Among the emotions associated with this form of protest, both groups indicated rage (anger), in addition, the 18-24 year old group also indicated dissatisfaction and such an associative universal as "scary". Positive emotions are not associated with this form of protest.

In the category "protest", both groups have associations with uprising, struggle and revolution. A group of 18-24 years of age has more similar associations, for example, there is a connection between riot and such a form of rebellion as mutiny. The abundance of associations with armed forms of protest in this category confirms that in the minds of the respondents this form of protest behavior is perceived as one of the most severe and violent.

In the category "historical and cultural connotations" there are various associations with past events and literary images. The respondents cited a catch phrase about the Russian riot from the work of A.S. Pushkin: "Nonsensical and ruthless". In the collective memory there is also the Salt Riot, and the 25-30 years olds indicated Pugachev.

The semantic analysis showed that riot is associated with blood and destruction, is connected in the respondents' opinion with the most violent forms of protest, has many negative associations. On the contrary, there is almost no connection with any creative values and goals. 
Young people in both groups do not perceive it as a meaningful form of protest. On the unconscious level, riot is associated with aggression, discontent and death.

We can say that this form of protest becomes relevant when young people have a large charge of negative emotions, as their splash in struggle and destruction.

Youth perception of uprising. A group of young people aged 18-24 gave 301 associations for the stimulus "uprising". The 25-30 age group provided 289 associations. The semantic analysis of the associative material for the stimulus "uprising" shows that in the 1824-year-old group the image of uprising is associated with such values as justice, change and opportunities. In the group is 25-30 years old - with freedom and a change of power. However, the volume of such associations with values is much less than that of such stimuli as rallies and petitions. On a conscious level, uprising is rarely seen as a form of achieving social and political goals.

The subjects of action are, on the one hand, the public, people, on the other - the police, the military and government. Uprising, as well as a rally, is perceived by the respondents as a form of "the people's" protest.

In this case, the association "power" can refer to both the race for power and confrontation between the people and the government.

For both groups, the uprising is associated with shooting and weapons, that is, with militaristic attributes. The category "negative symbols" contains numerous associations with death and pain.

In the category "emotions," this stimulus causes fear in both groups. Moreover, if a group of 18-24 years old also associates with it anger and discontent, then young adults associate only fear and horror.

For both groups, ideas about uprising are associated with such related concepts as revolution, coup, struggle, riot, war.

In the 25-30-year-old group, the "uprising" stimulus is associated with a wide range of historical and cultural meanings, such as Lenin, a Tsar, the Decembrists, the Reds. The group aged 18-24 has noticeably fewer such associations. Young adults (25-30 years old) are bearers of a collective historical memory of the Soviet and pre-revolutionary periods. In the minds of the youth group, these values are much weaker. Probably, there is a loss of historical memory of many events in Russian history.

Thus, such a form of protest as uprising is well known to both groups of young people. This form of protest in the minds of respondents has less connection with creative values than a rally. Uprising in the minds of young people is associated with such concepts as freedom, justice, change.

At the unconscious level, it is perceived as a struggle generated by anger and discontent. The semantic analysis showed that at the unconscious level the image of uprising has clear connections with such phenomena as death, fear, blood.

\section{Reconstruction of Perceptions About the Forms of Protest Using the Semantic Differential}

Next, we will present the results of reconstruction of perceptions about the forms of protest using the SD for assessing the protest. This method allows us to supplement the data of the associative experiment. 
The material of associations reflects both unconscious and rational components of perceptions. And the SD data correspond to the conscious assessment of these phenomena by the respondents. Being reduced with the help of factor analysis procedures, the system of assessing forms of protest makes it possible to reveal the respondents' structures of thinking. Our task was to understand which main categories of assessment are used by young people to assess the main forms of protest.

Below is a reconstruction of the factor structure of the respondents' assessment of the "meeting" stimulus as the form of protest most relevant for young people, and the "uprising" stimulus as the most radical one. The structure of evaluating the "strike" stimulus is also analyzed.

Comparison of the factor structures of assessing the three forms of protest made it possible to reveal the presence of common assessment categories. These include four factors that are found in almost all reconstructions.

Table (1): Categorical structure of perception of forms of social protest (general categories)

\begin{tabular}{|l|l|}
\hline No & Names of factors \\
\hline 1 & "Intelligence and honesty" \\
\hline 2 & "Hypocrisy and cupidity" \\
\hline 3 & "Peace - aggressiveness" \\
\hline 4 & "Strength" \\
\hline
\end{tabular}

The most voluminous factor in terms of the chosen variance is "Intelligence and honesty". It is found in all reconstructions without exception; accordingly, its structure reflects an important "axis" in assessment of the protest by the youth of both groups.

In assessing protest for both age groups, the most important characteristics are honesty and intelligence. The connection between these two characteristics is probably non-accidental. At a deep level of thinking, the concepts of intellectual and honest are closely related. This is likely to have an impact on the everyday level as well. As we can assume, a protest assessed as an intellectual one inspires more confidence in young people. Feedback is also possible.

Such characteristics as intelligent and honest in reconstruction usually correlate with such characteristics as attractive and good. For the 25-30 age group, in addition, they are interconnected with the concept "peaceful". This means that intelligent and honest protest is attractive to young people. The scale "attractive" is a marker of positive attitude.

The next key axis for assessing protest actions is reflected in the factor "Hypocrisy and cupidity". Its presence in all reconstructions means high importance of these categories. For the youth of both groups, it is important whether the protests have such negative features as cupidity and hypocrisy. For a group aged 18-24, these qualities make the protest "alien". The characteristic "alien" is a marker of unattractiveness for both groups.

These two characteristics, hypocrisy and cupidity, are, as you can see, steadily interconnected in the minds of the respondents. As you can imagine, with such a stable relationship between these two categories, they will influence each other. A protest action that is perceived as hypocritical is likely to be perceived by young people as mercenary in nature, and vice versa.

In addition, cupidity and hypocrisy in the respondents' opinion are often associated with aggressiveness.

Another very important factor is "Peace - aggressiveness". It is important for the youth of both groups whether the protest is peaceful and open. A special importance of the category of 
peace is confirmed by the presence in some reconstructions of such an axis of assessment as the factor "Peace - Evil and hypocrisy".

"Aggressive" protest is also perceived as "scary" and "alien". This means that aggressiveness is frightening, associates with increasing fear. At the opposite pole of this factor there is "peace". This concept is perceived as opposite to aggression and fear.

The categories included in the "strength" factor, such as strong, fast and active, reflect the dynamics and scale of a protest process. The characteristic "strength" is mostly neutral, but in the 25-30 age group, strength is sometimes intertwined with categories of aggressiveness. That is, strength and activity can be intimidating, possibly due to an uncontrollable nature, as well as due to consequences.

If we imagine an image of a "perfect protest", then for both groups it is an intellectual, honest, peaceful process. On the other end of the spectrum there is a mercenary, hypocritical and aggressive protest.

\section{Conclusions}

First of all, the analysis of SD data made it possible to identify the most important axes for evaluating various forms of protest. General categories have been identified. They include four factors that are found in almost all reconstructions.

These factors include several key characteristics that young people in both groups use to assess and comprehend protest phenomena.

First of all, it is important for young people to have such qualities as intelligence and honesty in the protest movement. The presence of these qualities inspires confidence, makes the protest attractive.

On the contrary, qualities such as cupidity and hypocrisy are unattractive to young people in both age groups. Their presence is undesirable and makes the protest "alien".

Categories such as aggressiveness and anger are also unattractive to young people. In their minds, these categories are associated with fear and unattractiveness. The inverse category in this axis of assessment is "peace". It is important for the youth of both groups whether the protest is peaceful and open.

If we imagine the image of a "perfect protest", then for both groups it is an intellectual, honest, peaceful process. On the other end of the spectrum there is a mercenary, hypocritical and aggressive protest.

If we compare perceptions of the forms of protest in terms of saturation with values, then there is a noticeably rich content of the category "values and goals" for such incentives as rally and petition. Rallies are perceived mostly positively, being associated with key political and existential values. Both groups associate rallies with such concepts as freedom, rights, justice, democracy. This form of protest is perceived by young people as a manifestation of direct democracy, active defense of rights and justice in the urban environment. If we take into account the categories of assessing a protest, then rally will be the most attractive for broad strata of young people in a peaceful manner. It will also be more attractive if there is a certain intellectual level, faith in honesty of intentions of its organizers and participants. Conversely, doubts in honesty and low intellectual level will make such an event unattractive for many young people. 
A petition is associated in the respondents' minds with s hope for change, with protection of rights, ability to draw attention to certain problems. We believe that these forms are the closest to young people.

Such a form of protest and participation as petition seems to be quite modern, corresponding to young people's digital consciousness. However, its potential has not been fully used. If we compare the data of associations and SD, then according to the axes we have identified for evaluating the protest, petition should be evaluated positively. It corresponds to the category of peaceful protest, does not bear aggressiveness. Petition as a form of participation may well correspond to the categories of intelligence and honesty. It is possible to recommend that public authorities pay attention to the opportunities provided by such a form of political activity as petition. It may well be an effective form of expression of views of young people, including protests, and at the same time be a channel of communication between the authorities and society.

Such forms as online petitions and various polls can satisfy a number of needs of the younger generation in expression of opinions, emotions, participation in public affairs and communication. At the same time, this is a legal form of participation that does not carry a destructive potential.

Such a form of protest as a strike, in the minds of young people, is almost not associated with political and existential values, it is mainly perceived as a means of struggle for economic rights. Strike as a form of political and social activity is well known to the youth of both groups, it has connections with historical memory.

Comparison of the obtained material allows us to conclude that the incentives "uprising" and "riot" have a similar semantic field. Semantic analysis showed that riot and uprising are associated with blood and destruction, are linked in the respondents' opinion with the most violent forms of protest, have many negative associations. A riot has almost no connection with any creative values and goals in the collective consciousness. This form is perceived negatively both on the emotional, unconscious, and rational levels. This is confirmed by the data of reconstruction of the categories of protest assessment. Comparing associative universals and SD scales, it is possible to determine orientation of assessment of forms of protest by some factors. Taking into account severity of perceptions of a riot as a meaningless phenomenon, it will be assessed negatively according to the factor of "Intelligence and honesty". Young people are looking for meaning in protest; its intellectual level is important for them.

According to the factor "Peace - aggressiveness", these two forms of protest will be assessed as aggressive, which means scary, alien.

It can be said that the youth of both groups do not seek extreme forms of protest, such as riot and uprising, and do not consider them optimal. Uprising, however, despite numerous negative associations, in the collective consciousness of young people still has a connection with such significant values as freedom, justice, changes. As we believe, in a normal situation, the categorical system of thinking of young people will disqualify it as a form of political and social participation. The situation can change in an extreme social situation.

On the unconscious level, images of riot and uprising are associated with aggression, discontent and death. Among the emotions associated with them there are anger, rage and fear. It can be said that these two extreme forms of protest can become relevant if young people have a large charge of negative emotions, and there is no opportunity to express these emotions through more peaceful forms of protest. With long-term group deprivation and the absence or ignorance of peaceful and legal ways of realizing discontent, such a way as violent protest can be realized. In this case, a riot will be a spontaneous outburst of aggression, devoid of purpose, 
and an uprising, also representing manifestation of negative emotions, can be a meaningful and organized process.

Probably the closest in spirit for young people is such a form of protest as a rally. For both groups, rallies are associated with key existential and political values. In particular, in the minds of both groups of young people, rallies are associated with such concepts as "democracy" and "justice". This form of protest is perceived by young people as a manifestation of direct democracy.

Rallies can be both emotionally and rationally attractive to young people. If a rally and its organizers are assessed positively in terms of the categories of assessing the protest, they are perceived as honest and intellectual, they can find support of young people. This is generally confirmed by observed events.

As this study has shown, the idea of rallies is not associated with images of uprising, revolution. If a group of 18-24 years old associates a rally with struggle, then young people 2530 years old - with peaceful forms of expression: demonstrations, marches.

It seems that participation of young people in rallies, including unauthorized ones, at this stage does not pose a great threat to the state. It could be recommended to consider them as a kind of natural form for young people to express opinions and accumulated emotions. It should be borne in mind that such a form of public activity as a rally is consonant with the heightened striving of these generations for freedom and activity.

On the contrary, heavy-handed suppression and prohibition of this form of protest can build tensions and heighten interest to more radical forms of protest.

Comparison of the materials obtained with the help of the two applied methods allows us to assess both the rational and the deeper, based on emotions and images, aspects of ideas about the protest and its comprehension. In this case, the rational and unconscious levels of response may not coincide. It seems that in a usual situation, a person and a group try to solve their problems within a social framework, guided by common sense and reason. However, arising sometimes long-term impossibility of solving problems gives rise to deprivation. The more critical the situation becomes and the fewer are opportunities for solving problems in a rational way, the more likely it is activating of deeper, emotion-based response mechanisms.

The conducted research has revealed some interesting patterns of protest consciousness. This topic seems to merit further study. The obtained materials can be useful to government bodies, political parties, educational institutions. The study of this topic will be continued.

\section{Funding}

The reported study was funded by RFBR and EISR, project number 20-011-31-518.

\section{References}

Akunina, Ju.A. (2011). Molodezhnye dvizhenija sovremennoj Rossii: protest i sozidanie [Youth movements in modern Russia: protest and creativity]. Vestnik MGUKI, 3(41): 123-127.

Baranova, G.V. (2012). Metodika analiza protestnoj aktivnosti naselenija Rossii [The method of analysis of protest activity of the population of Russia]. Sociologicheskie issledovanija, 10: 143-152.

Bushuev, D.V. (2012). Specifika protestnoj aktivnosti rossijskoj molode-zhi v sovremennom transformirujushhemsja obshhestve [The specifics of the protest activity of Russian youth in contemporary transforming society]: avtoref. dis.. kand. sociol. nauk: 
22.00.04 [abstract dis. ... candidate of sociological sciences: 22.00.04]. Rostov on Don: FGAOU VPO "Southern Federal University".

Davis, J. (1959). A formal interpretation of the theory of relative deprivation. Sociometry, 22(4): 280-296.

Gaba, O.I. (2015). Molodezh' kak sub\#ekt protestnyh nastroenij [Youth as a subject of protest]. Znanie, ponimanie, umenie, 1: 144-151.

Kamans, E., Otten, S., Gordijn, E.H. (2011). Threat and power in intergroup conflict: How threat determines emotional and behavioral reactions in powerless groups. Group Processes and Intergroup Relations, 14: 293-310.

Klandermans, B., Van Der Toorn, J., Van Stekelenburg, J. (2008). Embeddedness and identity: How immigrants turn grievances action. American Sociological Review, 73: 992-1012.

Krasin, Ju.A. (2012). Fenomen ulichnyh protestov i koleja rossijskogo vybora [The phenomenon of street protests and Russian choice track]. Monitoring obshhestvennogo mnenija: jekonomicheskie i social'nye peremeny, 3: 92-99.

Nazarov, M.M. (1995). Politicheskij protest: opyt jempiricheskogo analiza [Political protest: an empirical evidence]. Sociologicheskie issledovanija, 1: 47.

McClurg, S.D. (2003). Social networks and political participation: The role of social interaction in explaining political participation. Political Research Quarterly, 56: 448-464.

Petrenko, V.F. (2005). "Psihosemanticheskij analiz imidzha politicheskih liderov [Psychosemantic analysis of the image of political leaders]", in: V,F. Petrenko, Osnovy psihosemantiki. St. Petersburg: Piter.

Petrenko, V.F., Gladkih, N.Ju., Mitina, O.V. (2016). Psihosemanticheskij analiz vosprijatija politicheskih liderov (na materiale vyborki studentov iz Juzhnoj Korei) [Psychosemantic analysis of the perception of political leaders (based on a sample of students from South Korea)]. Vestnik Moskovskogo universiteta. Serija 14. Psihologija, 2: 64-87.

Petrenko, V.F., Mitina, O.V. (1997). Psihosemanticheskij analiz dinamiki obshhestvennogo soznanija [Psychosemantic analysis of the dynamics of public consciousness]. Moscow: Izd-vo Mosk. un-ta.

Petrenko, V.F., Mitina, O.V. (2017). Psihosemanticheskij podhod v rekonstrukcii politicheskogo mentaliteta: metody i primery issledovanij [Psychosemantic approach in the reconstruction of political mentality: methods and examples of research]. Vestnik Rossijskoj akademii nauk, 87(1): 50-64.

Petrushina, A.V. (2011). Protestnoe uchastie molodezhi v sovremennom rossijskom obshhestve [The protest participation of young people in contemporary Russian society]. Izvestija Tul'skogo gosudarstvennogo universiteta. Gumanitarnye nauki, 1: $337-346$.

Serkin, V.P. (2008). Metody psihologii sub\#ektivnoj semantiki i psihosemantiki: Ucheb. posobie dlja vuzov [Methods of psychology of subjective semantics and psychosemantics: Textbook, manual for universities]. Moscow: Izdatel'stvo PChELA.

Serkin, V.P. (2009). Reshenie zadachi o sluchajnosti / ne sluchajnosti associacij: kriterij ocenki i validnyj nabor associacij [Solving the problem of randomness / nonrandomness of associations: evaluation criteria and a valid set of associations]. Psihodiagnostika, 4: 24.

Shestopal, E.B., Nesterova, S.V., Bukreeva, O.V., Smul'kina, N.V., Zatonskih, A.V., Titov, V.V. (2012a). Obrazy kandidatov v prezidenty $2012 \mathrm{v}$ massovom soznanii [Images of presidential candidates 2012 in the public mind]. Vlast', 3: 186-190.

Shestopal, E.B., Novikova-Grund, M.V. (1996). Vosprijatie obrazov dvenadcati vedushhih rossijskih politikov (psihologicheskij i lingvisticheskij analiz) [Perception of the images of the twelve leading Russian politicians (psychological and linguistic analysis)]. Polis, 5: 168-191. 
Shestopal, E.B., Shutov, A.Ju., Volodenkov, S.V., Gaman-Golutvina, O.V., Lapkin, V.V., Makarenko, B.I., Mezhuev, B.V., M El'vil', A.Ju., Smul'kina, N.V., Nesterova, S.V. (2012b). Obrazy liderov $\mathrm{v}$ massovom soznanii nakanune prezidentskih vyborov [Images of leaders in the public mind on the eve of the presidential election]. Polis, 4: $160-174$.

Shmelev, A.G., Pohil'ko, V.I., Kozlovskaja-Tel'nova, A.Ju. (1988). Praktikum po jeksperimental'noj psihosemantike. Tezaurus lichnostnyh chert. [Workshop on experimental psychosemantics. Thesaurus of personality traits]. Moscow: MSU Publishing House.

Solomatina, E.N. (2014). Social'nye protesty v sovremennom mire: sociologicheskij analiz [Social protests in the modern world: sociological analysis]. Vestnik Nizhegorodskogo universiteta im. N. I. Lobachevskogo. Serija Social'nye nauki, 1: 103-107.

Van Zomeren, M., Postmes, T., Spears, R. (2008). Toward an integrative social identity model of collective action: A quantitative research synthesis of three sociopsychological perspectives. Psychological Bulletin, 134: 504-535.

Volkov, D. (2012). Protestnye mitingi v Rossii konca 2011 - nachala 2012 gg.: zapros na modernizaciju politicheskih institutov [Protest rallies in Russia in late 2011 and early 2012: the request for the modernization of political institutions]. Vestnik obshhestvennogo mnenija, 2(112): 73-86.

Wright, S.C., Taylor, D.M., Moghaddam, F.M. (1990). The relationship of perceptions and emotions to behavior in the face of collective inequality. Social Justice Research, 4: 229-250.

Zverev, A.L., Palitaj, I.S., R Ogozar', A.I., Smul'kina, N.V. (2016). Osobennosti politicheskogo vosprijatija $\mathrm{v}$ sovremennyh rossijskih uslovijah [Features of political perception in modern Russian conditions]. Polis, 3: 40-54. 